\title{
Research on the Influence of Managers' Self-Serving Attributive Behavior on Enterprise Investment Efficiency
}

\author{
Ziyan Di \\ Nanjing Normal University, Nanjing, China \\ Email: rabbitzoo@163.com
}

How to cite this paper: Di, Z.Y. (2019) Research on the Influence of Managers' Self-Serving Attributive Behavior on Enterprise Investment Efficiency. Open Journal of Social Sciences, 7, 362-378. https://doi.org/10.4236/jss.2019.74029

Received: March 27, 2019

Accepted: April 25, 2019

Published: April 28, 2019

Copyright $\odot 2019$ by author(s) and Scientific Research Publishing Inc. This work is licensed under the Creative Commons Attribution International License (CC BY 4.0).

http://creativecommons.org/licenses/by/4.0/

Open Access

\begin{abstract}
Corporate investment behavior has always been a matter of great concern. It is the main force for corporate growth and basis for future cash flow growth. Investment will directly affect the profitability and operational risks of enterprises, and will also affect financing and dividend distribution and series of corporate financial policies. However, there is always a large number of under-investment or over-investment behavior in enterprises in reality, which is also called the non-efficiency investment by enterprises. In addition to macro factors, the behavior and psychological deviation of manager also has an impact on corporate investment behavior. From the perspective of behavioral finance, this paper draws on the phenomenon of psychological deviation of people's overconfidence in psychology, and measures the overconfidence of managers in 2015-2017. The impact of behavior on corporate investment efficiency attempts to provide theoretical explanations and empirical evidence for the phenomenon of non-efficiency investment.
\end{abstract}

\section{Keywords}

Behavioral Finance, Self-Serving Attribution, Non-Efficiency Investment

\section{Introduction}

Investment decision-making activities have always been one of the most important activities in the daily operation of enterprises, and economics and management scholars have included it in the research of important topics. In terms of value sources, investment decisions determine the company's sustainable growth and future cash flow. Enterprises invest in order to gain more benefits to expand production and determine the source of enterprise value. Based on the impor- 
tant position of investment activities, it has quickly become the core of modern enterprise finance theory research. The early investment theory came into being in the 1870s. With the continuous improvement and development of investment theory, the classic capital structure theory and corporate governance theory were widely used in investment fields.

In recent years, the studies have greatly enriched people's understanding of enterprise investment behavior. These studies and explanations are based on the assumptions of rational man; however, the reality challenges this strict assumption. A large number of psychological studies have shown that human behavioral decisions are usually at a level that is not completely rational. In reality, the main manifestations of cognitive bias are: excessive optimism, confirmation bias, loss avoidance, control illusion, group effect behavior, etc. Too much belief in one's ability to judge and to overestimate the probability of success is the most common and serious overconfidence of knowledge. Overconfidence can be found in many work areas, such as engineers, doctors, nurses, lawyers, managers and entrepreneurs, but research has found that managers are more likely to be overconfident than the normal person.

The market economic system is not perfect in our country; listed companies still need a large number of inefficient investment. The pursuit of diversification will lead to overinvestment due to the lax supervision of funds within listed companies. Overinvestment is not only a waste of resources, but also will suffer the interests of investors and enterprise. In view of such prominent problems in listed companies, scholars began to conduct extensive research. However, the traditional theoretical framework of implicit manager assumption was mainly adopted to elaborate the research on the basis of principal-agent conflict and promote the use of incentive measures to coordinate the interests of managers and shareholders. However, most enterprises have agency problems, and it is difficult to solve them effectively from the perspective of incentive mechanism. In the context of a market economy dominated by the state, irrational behaviors of enterprise managers in actual investment decisions often occur. The irrational behavior of managers usually damages enterprise value and restricts the existence and development of listed companies theoretically. Because managers have the psychological characteristics of cognitive deviation, they cannot accurately carry out self-evaluation, and it is difficult for them to achieve the effect by taking incentive measures. This shows that the inefficient investment of governance managers should start from the cognitive characteristics of decision makers. From the existing research in China, there are relatively few studies on how the irrational behavior of managers affects the decision-making behavior of companies. Moreover, there is no complete theoretical framework for the research on the irrational behavior of managers from the perspective of behavioral finance. Whether we can use foreign research methods to study the listed companies in China is worth discussing. 


\section{Research Based on Psychology Self-Serving Attribution Theory}

\subsection{Psychological Bases for the Measurement of Self-Serving Attribution}

Behavioral finance theory absorbs a lot of knowledge of modern psychology, and explains the abnormal phenomenon of financial participants when they make investment decisions from the perspective of psychology. Behavioral finance enterprise theory is derived from behavioral finance and has become a branch of behavioral finance. Scholars refer to the research results of psychology, sociology, behavioral science and other related fields, and relax the traditional theory that decision makers are completely rational assumptions, and introduce the cognitive bias of decision makers into investment decision-making behavior.

Tversky and Kahneman (1974) [1], famous representatives of behavioral finance, pointed out that people are not always completely rational when faced with uncertainty, and intuition-driven bias and frame dependence play an important role in decision-making. According to the survey conducted by Daniel and Hirshleifer (1998) [2], people are more willing to attribute good results to their own efforts and judgment decisions, and such a misunderstanding will lead to their overconfidence. Bowman (1976) [3], Bettman and Weitz (1983) [4], Baginski (2000) [5] found that self-interest attribution was generally prevalent in the annual accounting reports of enterprises. If the performance of the enterprise is excellent, then the manager thinks it is more due to their own factors, and if the performance of the enterprise is not good, then the manager is more due to external factors.

Shefrin (2001) [6] first put forward the theory of behavioral enterprise finance, which believes that in addition to the traditional agency costs, there are also behavioral costs caused by managers' irrational behaviors and the non-effectiveness of the market. With the expansion of research scope and the diversity of methods, western scholars began to specifically study the impact of irrational performance of managers on enterprises' investment decisions, financing decisions and dividend policies. Aerts (2001) [7] found that the description of managers of the same enterprise does not change much, especially when the performance of the enterprise has been growing steadily, and if the performance of the enterprise declines, the attribution will become to the market environment and so on. Sun Manli (2005) [8] tested the theory of self-serving attribution for the first time in China, and found that there was a significant difference in attribution tendency between enterprises with excellent performance and those with poor performance, which was consistent with the theory of self-serving attribution. Jiang Yapeng (2008) [9] found that managers mostly attributed the increase of earnings to internal factors such as managers' own actions, while attributed the decline of earnings to external factors such as economic fluctuations and policy changes, showing an obvious self-serving tendency. When selecting investment projects, overconfident managers usually optimistically overestimate the future 
return rate of the project and underestimate various risks that may be encountered. Therefore, decisions that managers believe to be reasonable may become invalid or even wrong decisions, which will cause serious losses to the enterprise.

In this paper, the research results of psychology are introduced into the research. According to the theory of psychological self-serving attribution, this paper expounds the relationship between self-serving behavior and managers' overconfidence, that is, the managers' overconfidence leads to self-serving attribution behavior, which is one of the manifestations of managers' overconfidence. At the same time, self-serving attribution behavior will help managers form the overconfident psychology.

Compared with other methods, the self-serving attribution measurement method is more reliable and effective both in terms of the selection basis of measurement variables and the error space of measurement variables. Through the establishment of the model and empirical analysis, this paper analyzes the impact of managers' self-serving attribution behavior on the investment efficiency of enterprises from the perspective of behavioral finance theory, which provides a new perspective for understanding the investment of enterprises and has theoretical significance for expanding the research depth and breadth.

\subsection{Selections of Research Data}

This paper selects the enterprises that publish the performance forecast for the Shenzhen-Shanghai A-shares from 2015 to 2017 as a sample, excluding financial industry enterprises and $\mathrm{ST}, \mathrm{ST}^{*}$ stock enterprises, and determines the initial sample. On this basis, the following enterprises were excluded: 1) A total of 229 enterprises which are repeatedly reported in the regular reports, including 71 in 2015, 68 in 2016, and 90 in 2017. 2) A total of 108 enterprises with revised notices, including 35 in 2015, 32 in 2016 and 41 in 2017. 3) A total of 31 companies with uncertain types of notices, including 7 in 2015, 8 in 2016 and 16 in 2017. 2178 effective samples are finally determined, including 752 in 2015, 756 in 2016 and 670 in 2017. The data comes from the CSMAR database.

\subsection{Measures of Self-Serving Attribution}

Content analysis method originated from the field of news communication. Until the 1990s, almost all media contents have become content analysis objects. Schwenk (1990) [10] experimentally verified the effect of self-serving attribution on information users. Baginski (2004) [11] took 2085 management predictions from 1983 to 1986 as samples, and the results showed that the existence and type of attribution had a significant impact on enterprises. This paper introduces content analysis method to analyze the linguistic information about performance attribution in performance forecast.

The measure of self-serving attribution is a method to measure the overconfidence of managers according to self-serving attribution behavior judgment. It refers to the reading analysis of the reasons for the changes in the performance 
of the company's performance forecast, and finds the attribution sentences in the textual expression, and measures the parts of the attribution information through text analysis, which means judging each attribution sentences tend to internal factors or external factors, and the self-serving attribution behavior tendency based on the influence of enterprise performance is positive or negative.

The judgment of self-serving attribution behavior is mainly based on the simple model proposed by Salancik and Meindl [12]. Sun Manli used this model for the first time in China to test the self-interest attribution theory. Later, Jiang Yapeng also used this classic model to judge the self-serving attribution behavior in research.

In this model, $\mathrm{X}$ represents the good development of the enterprise's operating results, and $\mathrm{Y}$ represents the bad development of the enterprise's operating results, A represents the internal influencing factors, and B represents the external influencing factors. According to this, AX indicates that the business operation has improved, which because of the correct judgment of the company itself, $\mathrm{BX}$ indicates that the business operation has improved, which because of factors other than the enterprise, AY indicates that the business operation has declined, and it is due to the wrong judgments of the enterprise itself, BY means that the business operation has declined, and it is due to factors other than the enterprise.

Obviously, when $\mathrm{AX}-\mathrm{BX}>0$, it means that the business operation has been improved, and the correct judgment of the enterprise itself has more influence than the factors outside the enterprise; when $\mathrm{BY}-\mathrm{AY}>0$, the business operation has been decreased, and it is the factors outside the enterprise have more influence than the enterprise's own wrong judgment. In both cases, the reason for the overconfidence of corporate managers is the impact of self-serving attribution factors. When $\mathrm{AX}-\mathrm{BX}<0$ or $\mathrm{BY}-\mathrm{AY}<0$, the managers' overconfidence is not very obvious, and the influence of self-serving factors is small or non-existent. We can find the above data in the CSMAR database.

The performance forecast of enterprises can be divided into nine types, of which four are rising, four are falling, and one is uncertain. In the actual research process, the samples of companies with uncertain factors will be removed. The external cause includes macroeconomic conditions, changes in national macroeconomic policies, seasonal factors, litigation/legal actions, product market changes, industry competition issues, climate/disasters, changes in mandatory accounting policies, changes in industry sentiment, regulatory actions by the SFC, changes in the cost of raw materials, industry (business) characteristics, product price changes, etc.; Internal cause includes product structure changes, management measures/strategies/actions/plans, advertising/marketing strategies, purchasing/dispose of assets (shares), new product development/production, control (participation) changes in the performance of the company, asset impairment (return), production changes, operating conditions, project investment, asset restructuring, etc. We can express the variable of self-serving attribution as a dummy variable, with a value of 0 or 1 . When $A X-B X+B Y-A Y>0$, it indicates that the manager has self-serving attribution, and the value is 1 ; When 
$\mathrm{AX}-\mathrm{BX}+\mathrm{BY}-\mathrm{AY}<0$, it indicates that the manager has no self-serving attribution, and the value is 0 .

\subsection{Measurement of Non-Efficiency Investment in Enterprises}

The investment efficiency of enterprises can be understood as follows, that is, there is an optimal investment level, and when the actual investment expenditure of enterprises deviates from this optimal level, overinvestment or underinvestment are both investment inefficiencies. Richardson (2006) [13] first put forward the model to estimate the optimal investment level, as formula (1). The fitting of the model value is the optimal level of investment enterprises, and the residual represents the deviation of actual investment on the optimal investment level. The smaller of the absolute value of the residual means the higher of the investment efficiency of the enterprise. On the contrary, the larger the absolute value of the residual shows that the enterprise investment efficiency is lower.

$$
\begin{aligned}
\text { Invest }_{i, t}= & \alpha_{0}+\alpha_{1} \text { Growth }_{i, t-1}+\alpha_{2} \operatorname{Lev}_{i, t-1}+\alpha_{3} \text { Cash }_{i, t-1}+\alpha_{4} \text { Duration }_{i, t-1} \\
& +\alpha_{5} \text { Size }_{i, t-1}+\alpha_{6} \text { Ret }_{i, t-1}+\alpha_{7} \text { Invest }_{i, t-1}+\sum \text { Industry }+\sum \text { year }+\varepsilon_{i, t}
\end{aligned}
$$

Invest is the new investment expenditure of the enterprise, which is equal to the sum of cash paid by the current fixed assets, intangible assets and other long-term assets divided by the total assets at the beginning; Growth is the value of Tobin Q, which is generally used in international research to represent the growth opportunity of the company. There are still a large number of non-tradable shares in China's listed enterprises, and it is not possible to accurately calculate the value of non-tradable shares by common methods, so use it to measure growth opportunities for listed companies may be biased. Cash is Cash holdings, which is equal to the sum of total cash and cash equivalents at the end of the period divided by the total assets at the end of the period; Lev is the asset-liability ratio of an enterprise and represents the capital structure of the company; Size is the size of the enterprise, which is the natural logarithm of assets; Duration refers to the listed age of the enterprise and represents the development stage of the company; Ret is stock return, which is the annual return of the stock considering the cash dividend reinvestments. Industry is the dummy variable of the Industry; Year is the dummy variable of the Year; "Overinvest" refers to overinvestment, which is equal to the residual greater than zero after the regression estimation of the expression. "Underinvest" means insufficient investment, which is equal to the absolute value of the residual less than zero after regression estimation of the expression value.

\subsection{Research Hypothesis and Models}

Psychological research shows that self-serving attribution is a typical and universal psychological bias. Humans have a tendency to make self-serving attributions, and business managers, most of whom are already successful, are apparently more overconfident. They overestimate their management ability and are willing to undertake high-risk projects. But in reality, the interests of managers 
and shareholders are inconsistent. In the context of China's equity structure, the chairman and the management have an obvious tendency of "isomorphism", and the control of the enterprise is mainly concentrated in the hands of the chairman, the management and other senior executives, which makes it difficult to control the enterprise's inefficient investment behavior. In order to build their own empire and control more enterprise resources, self-serving managers gain more private interests by investing in projects. Managers will be more willing to invest in projects that do not increase but decrease the enterprise value. Based on the above analysis, we assume that:

Hypothesis 1: Managers' self-serving attribution behavior is positively related to the degree of non-efficiency investment.

In this paper, model 2 was constructed to test hypothesis 1 : it is expected in this paper that when the sample is the listed enterprises with excessive investment, the coefficient of Overinvest is significantly positive, that is, managers' self-serving attribution aggravates the enterprise's over-investment $t$, thus reducing the investment efficiency. When the sample is the listed enterprises with under-investment, the coefficient of Overinvest is significantly negative, that is, the managers' self-serving attribution behavior corrects the lack of investment, thus improving the investment efficiency.

$$
\begin{aligned}
\text { Uneffinv }= & a_{0}+a_{1} \operatorname{Sa}_{i t}+a_{2} \text { Growth }_{i t}+a_{3} \text { Lev }+a_{4} \text { Size }_{i t}+a_{5} \text { Board }_{i t} \\
& +a_{6} \text { Top }_{i t}+a_{7} \text { Share }_{i t}+\sum \text { Industry }+\sum \text { Year }+\varepsilon_{i t}
\end{aligned}
$$

There are two kinds of effects of managers' self-serving attribution on the investment efficiency of enterprises. On the one hand, managers' self-serving attribution behavior can exacerbate excessive investment and reduce investment efficiency. On the other hand, managers' self-serving attribution behavior can correct the lack of investment and improve investment efficiency.

Malmendier and Tate (2004) [14] found that the overconfidence of managers can explain the investment distortions of enterprises. Overconfident managers overestimate the future benefits of the project, and when faced with the choice of financing channels, they usually choose internal financing because they think that external financing costs are very high. Due to the existence of principal-agent problems, optimistic and confident managers may establish their own "business kingdom" by putting sufficient cash flow into various projects. In this case, the project with negative net present value is also positive in their eyes, and they will choose a lot of non-shareholder wealth maximization projects to invest. Ye Bei and Yuan Jianguo (2008) [15] believe that the overconfidence of managers is positively related to the sensitivity of enterprise investment cash flow, while managers are overconfident that the investment decisions expressed may lead to inefficient investment of enterprises and may also improve the work of managers, so the overconfidence of managers is monotonously correlated with inefficient investment of enterprises.

Based on this, this paper proposes the following research hypotheses:

Hypothesis 2: managers with self-serving attribution behavior have higher 
sensitivity to investment cash flow.

In this paper, model 3 is constructed to test hypothesis 2: the cash flow of an enterprise is the main source of funds for its investment activities, so the cash flow has an impact on its investment.

The interaction term between self-serving attribution and cash flow indicates the impact of manager self-serving attribution on cash flow. In the investment equation of Malmendier and Tate [16], the main explanatory variable is the interaction term between overconfidence of managers and cash flow.

$$
\begin{aligned}
\text { Uneffinv }= & a_{0}+a_{1} S a_{i t}+a_{2} S a_{i t} \times F C F_{i t}+a_{3} F C F_{i t}+a_{4} \text { Growth }_{i t}+a_{5} \text { Lev }+a_{6} \text { Size }_{i t} \\
& +a_{7} \text { Board }_{i t}+a_{8} \text { Top }_{i t}+a_{9} \text { Share }_{i t}+\sum \text { Industry }+\sum \text { Year }+\varepsilon_{i t}
\end{aligned}
$$

Behavioral finance theory points out that managers have great differences in the degree of overconfidence due to their differences in gender, age, educational background and cultural background, so the investment behavior of enterprises will also have great differences (Preston et al., 2006) [17].

Although both men and women show overconfidence, men are generally more overconfident than women (Lundeberg et al., 1994) [18]. The systematic differences in the degree of confidence between men and women are most prominent in enterprise financial decisions (Beyer and Bowden, 1977) [19]. Many studies have shown that women are more risk-averse than men when investing. The evidence from Jianakoplos and Bernasek (1998) [20] suggests that female investors tend to adopt more cautious investment methods. Graham et al. (2002) [21] further explored the reasons for the differences in investment strategies between women and men. Men are highly selective about information, and often ignore details and information that they consider to be unimportant. Based on the above analysis, this paper proposes the following research hypotheses:

Hypothesis 3: male managers with self-serving attribution behavior are more likely to cause non-investment efficiency than female managers.

In this paper, model 4 was constructed to test hypothesis 3: the gender of managers was selected as the variable of managers' traits to test the influence on the relationship between managers' self-serving attribution and the investment efficiency of enterprises.

$$
\begin{aligned}
\text { Uneffinv }= & a_{0}+a_{1} S a_{i t}+a_{2} \mathrm{Sa}_{i t} \times \text { Gender }_{i t}+a_{3} \text { Gender }_{i t}+a_{4} \text { Growth }_{i t}+a_{5} \text { Lev } \\
& +a_{6} \text { Size }_{i t}+a_{7} \text { Board }_{i t}+a_{8} \text { Top }_{i t}+a_{9} \text { Share }_{i t}+\sum \text { Industry }+\sum \text { Year }+\varepsilon_{i t}
\end{aligned}
$$

The measurement methods of relevant variables are shown in Table 1.

\section{Regression Results}

\subsection{Experimental Results of Model 1}

1) Descriptive statistics of variables

In Table 2, the average value of investment expenditure was 0.0658 , and the minimum value was 0.00013 , indicating that the overall level of investment expenditure in the selected sample was relatively low. The average value of investment expenditure in the previous year was 0.0682 , and the standard deviation 
Table 1. Variable definition.

\begin{tabular}{|c|c|c|}
\hline & Variable & Metric method \\
\hline \multirow[t]{3}{*}{ Explained variables } & Invest & $\begin{array}{l}\text { (current fixed assets }+ \text { intangible assets }+ \text { other long-term } \\
\text { assets)/the total assets at the beginning }\end{array}$ \\
\hline & Overinv & $\begin{array}{l}\text { the residual greater than zero after the regression estimation } \\
\text { of the expression }\end{array}$ \\
\hline & Underinv & $\begin{array}{l}\text { the absolute value of the residual less than zero after } \\
\text { regression estimation of the expression value }\end{array}$ \\
\hline \multirow[t]{5}{*}{ Explanatory variables } & $\mathrm{Sa}$ & If self-serving Attributive exists, take 1 , otherwise, take 0 \\
\hline & $\mathrm{Sa} \times \mathrm{FCF}$ & $\begin{array}{l}\text { The interaction term between self-serving attribution and } \\
\text { free cash flow }\end{array}$ \\
\hline & FCF & $\begin{array}{l}\text { (net profit }+ \text { interest expense }+ \text { non-cash expense) - working } \\
\text { capital supplement }- \text { capital expenditure }\end{array}$ \\
\hline & Sa $\times$ Gender & $\begin{array}{l}\text { The interaction term between self-serving attribution and } \\
\text { gender }\end{array}$ \\
\hline & Gender & Men take 1 , women take 0 \\
\hline \multirow[t]{11}{*}{ Control variables } & Size & natural logarithm of assets \\
\hline & Ret & $\begin{array}{l}\text { the annual return of the stock considering the cash dividend } \\
\text { reinvestments }\end{array}$ \\
\hline & Cash & $\begin{array}{l}\text { (total cash }+ \text { cash equivalents at the end of the period)/the } \\
\text { total assets at the end of the period }\end{array}$ \\
\hline & Duration & the listed age of the enterprise \\
\hline & Lev & the asset-liability ratio of an enterprise \\
\hline & Growth & The value of Tobin $\mathrm{Q}$ \\
\hline & Top & $\begin{array}{l}\text { If the chairman and the general manager are the same } \\
\text { person, take } 0 \text {; otherwise, take } 1\end{array}$ \\
\hline & Board & Number of board members \\
\hline & Share & Proportion of shares held by the largest shareholder \\
\hline & Industry & The dummy variable of the Industry \\
\hline & Year & the dummy variable of the Year \\
\hline
\end{tabular}

Table 2. Descriptive statistics of variables.

\begin{tabular}{cccccc}
\hline Variable & Number & Mean & S. d & Min & Max \\
\hline Size & 5792 & 22.39 & 1.265 & 19.64 & 26.07 \\
Duration & 5792 & 12.67 & 6.064 & 3 & 23 \\
Lev & 5792 & 0.459 & 0.209 & 0.0656 & 0.972 \\
Growth & 5792 & 0.191 & 0.642 & -0.572 & 4.566 \\
Invest & 5792 & 0.0658 & 0.0942 & 0.00013 & 0.586 \\
Cash & 5792 & 0.167 & 0.116 & 0.0140 & 0.587 \\
Ret & 5792 & 0.351 & 0.579 & -0.4447 & 2.633 \\
\hline
\end{tabular}


was 0.0937. From the mean, the overall investment expenditure of enterprises showed a downward trend, and the volatility of the data of investment expenditure in that year was higher than that of the previous year. The mean value of Tobin $Q$ value is 0.191 , the minimum value is -0.572 , and the maximum value is 4.566. The difference between the minimum value and the maximum value is large, indicating that the growth gap of listed companies is large. The average size of the company is 22.39 , the minimum value is 19.64 , and the maximum value is 26.07 , which indicates that the scale of most of the companies is relatively large. The average asset-liability ratio is 0.459 , the maximum value is as high as 0.927 , and the minimum value is 0.0656 , which indicates that some enterprises' financial strategies are relatively conservative, while some enterprises' financial leverage is relatively large and the financial risks are relatively large. The mean value, maximum value and minimum value of cash holdings were $0.167,0.587$ and 0.014 , showing a significant difference.

2) Single factor test

It can be seen in Table 3 that in each year, the t-test of inter-group differences passed the significance level test of at least $5 \%$, indicating that there were significant differences in investment levels between the self-serving attribution sample group and the non-self-serving attribution sample group.

3) Regression analysis of inefficient investment

The regression results are shown in Table 4. The investment expenditure of the previous year was significantly positively correlated with the investment expenditure of the year at the level of $1 \%$. The regression coefficient was 0.2864 , which indicated that the investment expenditure of the previous year had a positive effect on the investment expenditure of the enterprise in the year. The more investment expenditure in the previous year, the forecast of enterprise investment projects is better, and the investment will be increased accordingly in the year. The regression coefficients of most of the remaining variables passed the significance level test.

\subsection{Experimental Results of Model 2}

1) Descriptive statistical analysis

The residual obtained by Model 1 is the non-efficiency investment. The residual difference is greater than 0 and less than 0 . If it is greater than 0 , it is over-investment. If it is less than 0 , it is under-investment. And the residual value

Table 3. Self-serving attribution of investment level difference test.

\begin{tabular}{cccccc}
\hline & \multicolumn{2}{c}{$\begin{array}{c}\text { Self-serving } \\
\text { attribution sample }\end{array}$} & \multicolumn{2}{c}{$\begin{array}{c}\text { Non-self-serving } \\
\text { attribution sample }\end{array}$} & $\begin{array}{c}\text { Inter-group } \\
\text { differences }\end{array}$ \\
\cline { 2 - 5 } & number & mean & number & mean & $-0.035^{\star * *}$ \\
2015 & 533 & 0.071 & 219 & 0.106 & $-0.021^{* *}$ \\
2016 & 550 & 0.070 & 206 & 0.090 & $-0.037^{* * *}$ \\
\hline
\end{tabular}


Table 4. Regression analysis of model 1.

\begin{tabular}{|c|c|}
\hline VARIABLES & Invest \\
\hline \multirow[t]{2}{*}{ Invest 1} & $0.2864^{* * *}$ \\
\hline & $(0.0138)$ \\
\hline \multirow[t]{2}{*}{ Growth 1} & $-0.0115^{* * *}$ \\
\hline & $(0.0020)$ \\
\hline \multirow[t]{2}{*}{ Size 1} & $-0.0068^{* * *}$ \\
\hline & $(0.0011)$ \\
\hline \multirow[t]{2}{*}{ Lev 1} & 0.0069 \\
\hline & $(0.0069)$ \\
\hline \multirow[t]{2}{*}{ Cash 1} & $0.0229^{* *}$ \\
\hline & $(0.0107)$ \\
\hline \multirow[t]{2}{*}{ Duration 1} & $-0.0007^{\star * *}$ \\
\hline & $(0.0002)$ \\
\hline \multirow[t]{2}{*}{ Ret 1} & $0.0180^{* * *}$ \\
\hline & $(0.0025)$ \\
\hline \multirow[t]{2}{*}{ Constant } & $0.1937^{\star * *}$ \\
\hline & $(0.0247)$ \\
\hline Observations & 5792 \\
\hline R-squared & 0.1257 \\
\hline
\end{tabular}

less than 0 is taken as absolute value. The over-investment and under-investment are taken as the explanatory variables, and the self-serving attribution of managers and the corresponding control variables are used for regression analysis. First, we descriptive statistical analysis is performed on each variable in Table 5.

The number of over-investment is 712 , and the number of under-investment is 1466. It can be seen that most of the listed companies selected in this paper have underinvestment behavior. The average value of self-serving attribution of managers is 0.701 , indicating that most managers have self-serving attribution behavior. The mean value of Tobin Q is 2.649 , the median is 1.934 , and the standard deviation is 2.447 , indicating that the data of Tobin $\mathrm{Q}$ is relatively scattered. The average asset-liability ratio was 0.439 , with a median of 0.429 and a standard deviation of 0.205 . The average size of the company is 22.23 , and the standard deviation is 1.146 , indicating that most companies have larger scales. The average size of the board of directors is 8.607 . The average of the two jobs is 0.735 , indicating that the chairman and general manager of most companies are not the same person. The average shareholding ratio of the largest shareholder is 0.323 , the maximum value is 0.724 , and the minimum value is 0.0833 , indicating that the shareholding ratio of the largest shareholder of the listed company is large.

2) Regression analysis

Table 6 reports the regression results of the influence of self-serving attribution on non-efficiency investment of managers in the overinvestment and underinvestment groups. From the overall regression, the fitting degree of the model is 
Table 5. Descriptive statistics of variables.

\begin{tabular}{ccccccc}
\hline variable & $\mathrm{N}$ & mean & median & $\max$ & $\min$ & $\mathrm{sd}$ \\
\hline Overinvest & 712 & 0.0847 & 0.0395 & 0.505 & 0.000771 & 0.116 \\
Underinvest & 1466 & 0.0374 & 0.0340 & 0.142 & 0.000645 & 0.0255 \\
Sa & 2178 & 0.701 & 1 & 1 & 0 & 0.458 \\
Growth & 2178 & 2.649 & 1.934 & 14.48 & 0.226 & 2.447 \\
Lev & 2178 & 0.439 & 0.429 & 0.886 & 0.0569 & 0.205 \\
Size & 2178 & 22.39 & 22.23 & 25.85 & 19.96 & 1.146 \\
Board & 2178 & 8.607 & 9 & 15 & 5 & 1.698 \\
Top & 2178 & 0.735 & 1 & 1 & 0 & 0.442 \\
Share & 2178 & 0.323 & 0.301 & 0.724 & 0.0833 & 0.144 \\
FCF & 2178 & 0.0329 & 0.0313 & 0.353 & -0.341 & 0.108 \\
Gender & 2178 & 0.964 & 1 & 1 & 0 & 0.186 \\
\hline
\end{tabular}

Table 6. Regression analysis of self-serving attribution and non-efficiency investment.

\begin{tabular}{ccc}
\hline VARIABLES & Overinvest & Underinvest \\
\hline Sa & $0.1017^{* * *}$ & $-0.0078^{* * *}$ \\
& $(0.0036)$ & $(0.0018)$ \\
Growth & $0.0027^{* * *}$ & $0.0011^{* * *}$ \\
& $(0.0008)$ & $(0.0001)$ \\
Lev & 0.0191 & 0.0007 \\
& $(0.0154)$ & $(0.0032)$ \\
Size & $0.0054^{* * *}$ & -0.0002 \\
& $(0.0014)$ & $(0.0009)$ \\
Board & $-0.0020^{* *}$ & $0.0007^{* *}$ \\
& $(0.0010)$ & $(0.0003)$ \\
Top & -0.0017 & $-0.0011^{* *}$ \\
& $(0.0034)$ & $(0.0004)$ \\
Share & -0.0072 & 0.0004 \\
& $(0.0067)$ & $(0.0020)$ \\
Constant & $-0.0851^{* * *}$ & 0.0182 \\
Observations & $(0.0301)$ & $(0.0147)$ \\
R-squared & 712 & 1466 \\
& 0.5630 & 0.5251 \\
& & \\
& & \\
& &
\end{tabular}

relatively good. As can be seen from the regression results of overinvestment non-efficiency investment behavior, the regression coefficient of managers' self-serving attribution is 0.1017 , which is significantly positive at the significance level of $1 \%$, indicating that managers' self-serving attribution will aggravate enterprises' overinvestment behavior. It can be seen from the regression results of underinvestment and non-efficiency investment behaviors, the regression coefficient of managers' self-serving attribution is -0.0078 , which is significantly negative at the significance level of $1 \%$, indicating that managers' self-serving at- 
tribution restrains enterprises' underinvestment behaviors to some extent, which verifies the hypothesis of this paper.

The growth of a company has a significant promoting effect on both overinvestment and underinvestment behavior, indicating that the higher the growth of the company, the deeper the degree of overinvestment and underinvestment. The asset-liability ratio has no obvious effect on overinvestment and underinvestment. The scale of a company has obvious promoting effect on overinvestment and insignificant negative effect on underinvestment. The scale of the board of directors has a significant inhibitory effect on overinvestment and a significant promoting effect on underinvestment. The combination of the two jobs has not obvious negative impact on overinvestment, but it has obvious negative impact on underinvestment.

\subsection{Experimental Results of Model 3 and 4}

Table 7 reports the regression results of the model 3 in the overinvestment and

Table 7. Regression analysis of interaction terms.

\begin{tabular}{|c|c|c|c|c|}
\hline \multirow{2}{*}{ VARIABLES } & \multicolumn{2}{|c|}{ Model 3} & \multicolumn{2}{|c|}{ Model 4} \\
\hline & Overinvest & Underinvest & Overinvest & Underinvest \\
\hline $\mathrm{Sa}$ & $\begin{array}{c}0.0747^{* * *} \\
(0.0039)\end{array}$ & $\begin{array}{c}-0.0079^{* * *} \\
(0.0014)\end{array}$ & $\begin{array}{c}0.0990^{* * *} \\
(0.0039)\end{array}$ & $\begin{array}{c}-0.0081^{\star * *} \\
(0.0019)\end{array}$ \\
\hline Gender & & & $\begin{array}{c}0.0878^{* * *} \\
(0.0124)\end{array}$ & $\begin{array}{l}-0.0013 \\
(0.0022)\end{array}$ \\
\hline Sa_Gender & & & $\begin{array}{c}0.1104^{\star * *} \\
(0.0136)\end{array}$ & $\begin{array}{l}-0.0001 \\
(0.0066)\end{array}$ \\
\hline FCF & $\begin{array}{c}0.2128^{* * *} \\
(0.0210)\end{array}$ & $\begin{array}{c}0.0302^{* * *} \\
(0.0045)\end{array}$ & & \\
\hline Sa_FCF & $\begin{array}{c}0.2306^{\star * *} \\
(0.0411)\end{array}$ & $\begin{array}{c}0.0145^{*} \\
(0.0086)\end{array}$ & & \\
\hline Growth & $\begin{array}{c}0.0021^{\star * *} \\
(0.0006)\end{array}$ & $\begin{array}{c}0.0011^{* * *} \\
(0.0001)\end{array}$ & $\begin{array}{c}0.0025^{\star * *} \\
(0.0007)\end{array}$ & $\begin{array}{c}0.0011^{\star * *} \\
(0.0001)\end{array}$ \\
\hline Lev & $\begin{array}{l}0.0268^{\star} \\
(0.0142)\end{array}$ & $\begin{array}{c}0.0001 \\
(0.0028)\end{array}$ & $\begin{array}{c}0.0210 \\
(0.0154)\end{array}$ & $\begin{array}{c}0.0007 \\
(0.0033)\end{array}$ \\
\hline Size & $\begin{array}{l}0.0043^{* * *} \\
(0.0011)\end{array}$ & $\begin{array}{l}-0.0001 \\
(0.0007)\end{array}$ & $\begin{array}{c}0.0052^{* * *} \\
(0.0015)\end{array}$ & $\begin{array}{l}-0.0002 \\
(0.0009)\end{array}$ \\
\hline Board & $\begin{array}{c}-0.0024^{* *} \\
(0.0010)\end{array}$ & $\begin{array}{l}0.0006^{* *} \\
(0.0002)\end{array}$ & $\begin{array}{c}-0.0021^{* *} \\
(0.0010)\end{array}$ & $\begin{array}{l}0.0007^{* *} \\
(0.0003)\end{array}$ \\
\hline Top & $\begin{array}{l}-0.0002 \\
(0.0052)\end{array}$ & $\begin{array}{c}-0.0010^{* * *} \\
(0.0003)\end{array}$ & $\begin{array}{l}-0.0012 \\
(0.0034)\end{array}$ & $\begin{array}{c}-0.0010^{\star *} \\
(0.0004)\end{array}$ \\
\hline Share & $\begin{array}{l}-0.0110 \\
(0.0068)\end{array}$ & $\begin{array}{l}-0.0007 \\
(0.0021)\end{array}$ & $\begin{array}{l}-0.0053 \\
(0.0059)\end{array}$ & $\begin{array}{c}0.0003 \\
(0.0020)\end{array}$ \\
\hline Constant & $\begin{array}{c}-0.0645^{\star * *} \\
(0.0249)\end{array}$ & $\begin{array}{c}0.0182 \\
(0.0111)\end{array}$ & $\begin{array}{c}-0.1648^{* * *} \\
(0.0215)\end{array}$ & $\begin{array}{c}0.0194 \\
(0.0133)\end{array}$ \\
\hline Observations & 712 & 1,466 & 712 & 1,466 \\
\hline R-squared & 0.5796 & 0.5414 & 0.5692 & 0.5252 \\
\hline
\end{tabular}


underinvestment group managers' self-serving attribution and free cash flow on the non-efficiency investment. From the regression result, it can be seen that the regression coefficient of the interaction term with free cash flow and manager's self-serving attribution is 0.2306 , which is positive at the $1 \%$ significance level, indicating that the higher the free cash flow, the promotion effect of the manager's self-serving attribution on the excessive investment behavior of the enterprise is stronger. It can be seen from the regression results of underinvestment and non-efficiency investment behavior that the regression coefficient of the interaction term between managerial self-serving attribution and free cash flow is 0.0145 , which is positive at the $10 \%$ significance level, indicating that if the free cash flow is lower, the managers' self-serving attribution will have a stronger inhibitory effect on the company's underinvestment behavior. The above model 4 reports the regression results of the self-serving attribution of the overinvestment and underinvestment group managers and the influence of the executive gender on the non-efficiency investment. The regression coefficient of the interaction term with free gender and managers' self-serving attribution is 0.1104 , which is positive at the level of significance of $1 \%$, indicating that compared with women, in enterprises with male executives, and managers' self-serving attribution plays a stronger role in promoting the excessive investment behavior of enterprises. As can be seen from the regression results of under-investment and non-efficiency investment behaviors, the regression coefficient of the interaction term between the self-serving attribution of managers and the gender of executives is -0.0001 , which has not passed the significance level test, indicating that there is no significant difference between the influence of the self-serving attribution of managers on the underinvestment in the case that the executives are male and the executives are female.

\section{Conclusions and Suggestions}

\subsection{Conclusions}

In order to explore the relationship between self-serving attribution of manager and enterprises' non-efficiency investment, this paper first summarizes and proposes the measurement method based on the psychological basis and behavioral finance theory: draw on Richardson's investment expectation model and use regression residual as a measure of the degree of enterprises' non-efficiency investment. Second, self-serving attribution is established with the investment efficiency of regression model. And the listed companies in the Shanghai-Shenzhen A-share transaction in 2015-2017 are selected as samples for research. Through the correlation test and the overall regression and grouping regression analysis, managers' self-serving attribution and the efficiency of the relationship between managers' self-serving attribution and inefficient investment are concluded.

Through empirical research, this paper comes to the following conclusions:

1) In the overinvestment group, the regression coefficient of managers' self-serving attribution was 0.1017 , which was positive at the significance level of $1 \%$, indi- 
cating that managers' self-serving attribution would aggravate enterprises' overinvestment behavior. In the underinvestment group, the regression coefficient of the managers' self-serving attribution was -0.0078 , which was negative at the significance level of $1 \%$, indicating that the managers' self-interested attribution inhibited the enterprises' underinvested behavior to some extent.

2) For managers with self-serving attribution, the higher the free cash flow is, the more likely it is to lead to overinvestment, while the lower the free cash flow is, the more obvious the inhibitory effect on underinvestment is.

3) It shows that compared with women, in enterprises with male executives, managers' self-serving attribution has a stronger promoting effect on enterprises' excessive investment behavior.

\subsection{Suggestions}

First, establish a set of mechanisms to constrain managers, and maximize the supervision of the adverse effects of self-serving managers' investment on enterprise investment. We can develop the characteristic index system of managers, effectively identify and measure the degree of confidence of managers, analyze the impact of self-serving attribution of managers on enterprise investment, financing and other behaviors, and timely restrict the decision-making activities of managers.

Second, improve accounting information disclosure standards. Although the annual report standard has been developed and implemented for more than 20 years, the contradiction between supply and demand based on information disclosure is still very prominent. Most listed companies are more inclined to attribute good performance to the internal conditions of the company, while bad performance is attributed to the external environment of the company, which provides the room for the company managers to make self-interested attribution. In this regard, the guidelines should clearly require that regardless of the performance, listed companies should fully analyze the opportunities and challenges of the external environment, as well as the advantages and disadvantages of internal management, while providing relevant evidence of market environmental impact; on the other hand, the Annual Report Guidelines clearly require "listing the changes and reasons for the company's operating income, costs, expenses, $R \& D$ investment, cash flow and other items", but there are still a large number of such things as "the decline in net profit is due to the decline in total profit". Manages' self-serving attribution as a psychological behavior tendency, cannot be well measured and disclosed. Listed companies should voluntarily disclose information about the company's development stage or future prospects, and actively improve the quality of information disclosure and the robustness of accounting, which can also properly form self-restraint on the self-serving attribution of the managers.

Third, improve the external supervision of certified public accountants. For managers who attribute self-serving, auditing can well restrain the behavior of 
management to despise conservatism and provide reasonable guarantee for financial report. Therefore, making full use of appropriate external supervision will appropriately constrain managers' self-serving attribution, and improve accounting conservatism. At the same time, in order to obtain more sales volume and click-through rate, the media will pay special attention to and report on the hot topic, and play the supervisory function of public opinion. Therefore, it is necessary to strengthen the external supervision of the performance attribution information of listed companies by news media, the public and market intermediaries, and increase the difficulty of the manipulation of performance attribution information, reducing the space for manipulation, and improving the transparency of information disclosure.

\section{Acknowledgements}

I would like to express my gratitude to all the teachers who have taught and helped me. It is their patient guidance and selfless teachings that equipped me with the knowledge and skills I should have mastered. I also want to thank my senior classmates for their help in my life and study. Their experience has saved me from many detours and improved my learning efficiency. I also want to thank my classmates for their help in my thesis writing.

\section{Conflicts of Interest}

The author declares no conflicts of interest regarding the publication of this paper.

\section{References}

[1] Tversky, A. and Kahneman, D. (1974) Judgment under Uncertainty: Heuristics and Biases. Science, 185, 1124-1131. https://doi.org/10.1126/science.185.4157.1124

[2] Daniel, K., Hirshleifer, D. and Subrahmanyam, A. (1998) Investor Psychology Security Market under and Over Reactions. The Journal of Finance, 153, 1839-1885. https://doi.org/10.1111/0022-1082.00077

[3] Bowman, E.H. (1976) Strategy and the Weather. Sloan Management Review, 17, 49-62.

[4] Bettman, J.R. and Weitz, B.A. (1983) Attributions in the Board Room: Causal Reasoning in Corporate Annual Reports. Administrative Science Quarterly, 28, 165-183. https://doi.org/10.2307/2392616

[5] Baginski, S.P., Hassell, J.M. and Hillison, W.A. (2000) Voluntary Causal Disclosures: Tendencies and Capital Market Reaction. Review of Quantitative Finance and Accounting, 15, 371-389. https://doi.org/10.1023/A:1012002608615

[6] Shefrin, H. (2001) Trading Volume, Information, and Trading Costs: Empirical Analysis. Journal of Banking and Finance, 18, 17-36.

[7] Aerts, W. (2001) Inertia in the Attributional Content of Annual Accounting Narratives. European Accounting Review, 10, 3-32. https://doi.org/10.1080/09638180122562

[8] Sun, M.L. (2005) The Empirical Study of Self-Serving Attribution Behavior in Annual Reports. Economic Science, 2, 82-93. 
[9] Jiang, Y.P. (2008) A Study on the Self-Serving Tendency of Earnings Change Attribution Information Disclosure of Listed Enterprises. Modern Management Science, 6, 117-119.

[10] Schwenk, C.R. (1990) Conflict in Organizational Decision Making: An Exploratory Study of Its Effects in For-Profit and Not-For-Profit Organizations. Management Science, 36, 436-448. https://doi.org/10.1287/mnsc.36.4.436

[11] Baginski, S.P., Hassell, J.M. and Kimbrough, M.D. (2004) Why Do Managers Explain Their Earnings Forecasts? Journal of Accounting Research, 42, 1-29. https://doi.org/10.1111/j.1475-679X.2004.00127.x

[12] Salancik, G.R. and Meindl, J.R. (1984) Corporate Attributions as Strategic Illusions of Management Control. Administrative Science Quarterly, 26, 238-254. https://doi.org/10.2307/2393176

[13] Richardson, S. (2006) Over-Investment of Free Cash Flow. Review of Accounting Studies, 11, 159-189. https://doi.org/10.1007/s11142-006-9012-1

[14] Malmendier, U. and Tate, G. (2004) CEO Overconfidence and Corporate Investment. The Journal of Finance, 60, 2661-2700. https://doi.org/10.1111/j.1540-6261.2005.00813.x

[15] Ye, B. and Yuan J.-G. (2008) Overconfidence of Managers, Moral Hazard and Corporate Investment Decisions. Finance and Accounting Monthly, 1, 5-8.

[16] Malmendier, U. and Tate, G. (2008) Who Make Acquisition? CEO Overconfidence and the Market's Reaction. Journal of Finance Economic, 89, 55-80.

https://doi.org/10.1016/j.jfineco.2007.07.002

[17] Kamas, L. and Preston, A. (2006) Can Social Preference Explain Gender Difference in Economic Behavior. Journal of Economic Behavior and Organization, 116, 525-539. https://doi.org/10.1016/j.jebo.2015.05.017

[18] Lundeberg, M.A., Fox, P.W. and Punćcohaŕ, J. (1994) Highly Confident but Wrong: Gender Differences and Similarities in Confidence Judgments. Journal of Educational Psychology, 86, 114-121. https://doi.org/10.1037/0022-0663.86.1.114

[19] Beyer, S. and Bowden, E.M. (1977) Gender Differences in Self-Perceptions Convergent Evidence from Three Measures of Accuracy and Bias. Personality and Social Psychology Bulletin, 23, 157-172. https://doi.org/10.1177/0146167297232005

[20] Jianakoplos, N, and Bernasek, A. (1998) Are Women More Risk Averse? Economic Inquiry, 36, 620-630. https://doi.org/10.1111/j.1465-7295.1998.tb01740.x

[21] Ben-David, I., Graham, J.R. and Harvey, C.R. (2002) Managerial Overconfidence and Corporate Policies. NBER Working Paper No. 13711. 